\title{
Significance of annulus fibrosus of heart in relation to AV conduction and ventricular activation in cases of Wolff-Parkinson-White syndrome
}

\author{
Antoine A. Verduyn Lunel \\ From the Department of Cardiology of the Academic Hospital, and from the Laboratory of \\ Anatomy and Embryology of the State University, Leiden, The Netherlands
}

A histological examination of accessory atrioventricular connecting fibres in two heart specimens with a Wolff-Parkinson-White (WPW) syndrome revealed the following findings.

Parietal subendocardial accessory fibres, mostly composed of ordinary myocardium, connected the atrial with the ventricular wall. In one specimen a few modified fibres were found between the parietal wall of the right atrium and that of the right ventricle.

Septal accessory fibres were also found. A part of these connexions was morphologically ordinary myocardium, but many other fibres were found to be bridges of conduction tissue between parts of the His-Tawara bundle and the basal rim of the ventricular septum.

Many holes were observed at different locations of the annulus fibrosus, at its parietal as well as at its septal part. It was noted that each hole was an anatomical pathway for at least one accessory fibre; more ordinary myocardial or modified connexions passed through a big gap.

It can be stated that the quantity of the accessory muscular atrioventricular connexions was determined by the degree of discontinuity of the annulus fibrosus. The latter structure appeared to be the most important component of the morphological substrate which was presumably related to the existence and a possible progression of atrioventricular and intraventricular conduction anomalies in cases of WPW syndrome.

The WPW syndrome, electrocardiographically characterized by a shortened PR interval and a prolonged QRS complex with an initial delta wave (Wolff, Parkinson, and White, 1930), was assumed to occur if a pacemaker impulse was conducted along a fibre which connected the atrium with the ventricle outside the morphologically proven muscular AV pathway, the His-Tawara bundle ( $\mathrm{Ta}$ wara, 1906). This was reported by OChnell (1940, 1944), Orinius (1967), and Durrer et al. (1967). Some authors postulated retrograde conduction through this fibre (Durrer et al, 1967; Burchell et al., 1967; Cobb et al., 1968; Roelandt and Van der Hauwaert, 1968).

Fibres connecting the atrium with the ventricle outside the His-Tawara bundle, described by Kent (1893, I914a, b, c), were called 'accessory' (Lev, Gibson, and Miller, I955; Lev et al., 1961, 1966; Lev, Sodi-Pallares,

Received 27 April 1972. and Friedland, 1963; Truex, Bishof, and Hoffman, 1958; Truex, Bishof, and Downing, 1960), because they were not found in the normal heart (Lev and Lerner, I955). In view of a lapse of more than 20 years between the first and second paper by Kent it seemed to be likely that the reported muscular AV connexions in man, in 1914, were related to a WPW syndrome. Studying the published reports about accessory fibres which were presumably related to the WPW syndrome there was an impression that only ordinary myocardial AV connexions were concerned (Wood, Wolferth, and Geckeler, 1943; Mahaim, 1947; Levine and Burge, I948; Truex et al., 1958, 1960; Burchell et al., 1967; Cobb et al., 1968). However, Kent (I9I4a, b, c) demonstrated in man bridges of conduction tissue between the atrial and ventricular wall at the right lateral AV junction. Histological examinations of two heart specimens with the WPW syndrome together with those reported 
(Kent, I914; Lev et al., 1966) reveal that the morphological substrate may comprise the following three components. (a) Parietal subendocardial accessory fibres; (b) septal accessory fibres of which one type was composed of ordinary myocardium while another type was found to be modified; (c) a discontinuous annulus fibrosus.

The quantity of accessory muscular AV connexions was found to be determined by the degree of discontinuity of the annulus fibrosus. The latter structure appeared to be the most important component of the morphological substrate which was presumably related to the conduction and activation disorders in cases of WPW syndrome.

The results of this histological study, and data concerning the same subject already published, are described and discussed in this paper.

\section{Case reports}

Case I A 31-year-old woman died during an operation for a commissurotomy because of severe mitral stenosis. This was diagnosed at the age of I5 years and at that time the electrocardiogram showed WPW syndrome. At the time of admission to the Cardiology Department of the Academic Hospital of Leiden, shortly before death, the cardiogram showed sinus rhythm (Fig. 1a). The PR interval was $0.16 \mathrm{sec}, \mathrm{QRS}$ complexes resembled in most leads type A WPW syndrome. A year before the admission the electrocardiogram questionably showed the $B$ type (Fig. Ib); in the spatial X, Y, and $Z$ leads there were complexes without WPW syndrome; others, respectively, had type A and type A plus type B pattern (Fig. IC).

Before operation many attacks of ventricular fibrillation occurred.

Necropsy Distinct enlargement of the left atrium, moderately dilated right and left ventricle. Very narrow mitral orifice which barely admitted a fingertip. Fibrosis of the left atrial endocardium and ventricular myocardium. Chronic congestion of the pulmonary veins with severe sclerosis of the pulmonary artery wall, chronic congestion of both lungs, and hypertrophy of the right ventricular wall. Chronic congestion of the liver and spleen and anaemia of the renal cortex.

Histological examination The following tissue blocks were taken from the heart specimen. The lateral junction of the right atrial and ventricular wall; the ventral junction of the right atrial and ventricular wall; the right lateral junction of the left atrial and ventricular wall; and the dorsal junction of the interatrial and interventricular septum. Each of the tissue blocks was hardened and then embedded in paraffin. Afterwards each block was cut transversely, at right angles to the coronary sulcus, in serial sections, each of which (a)
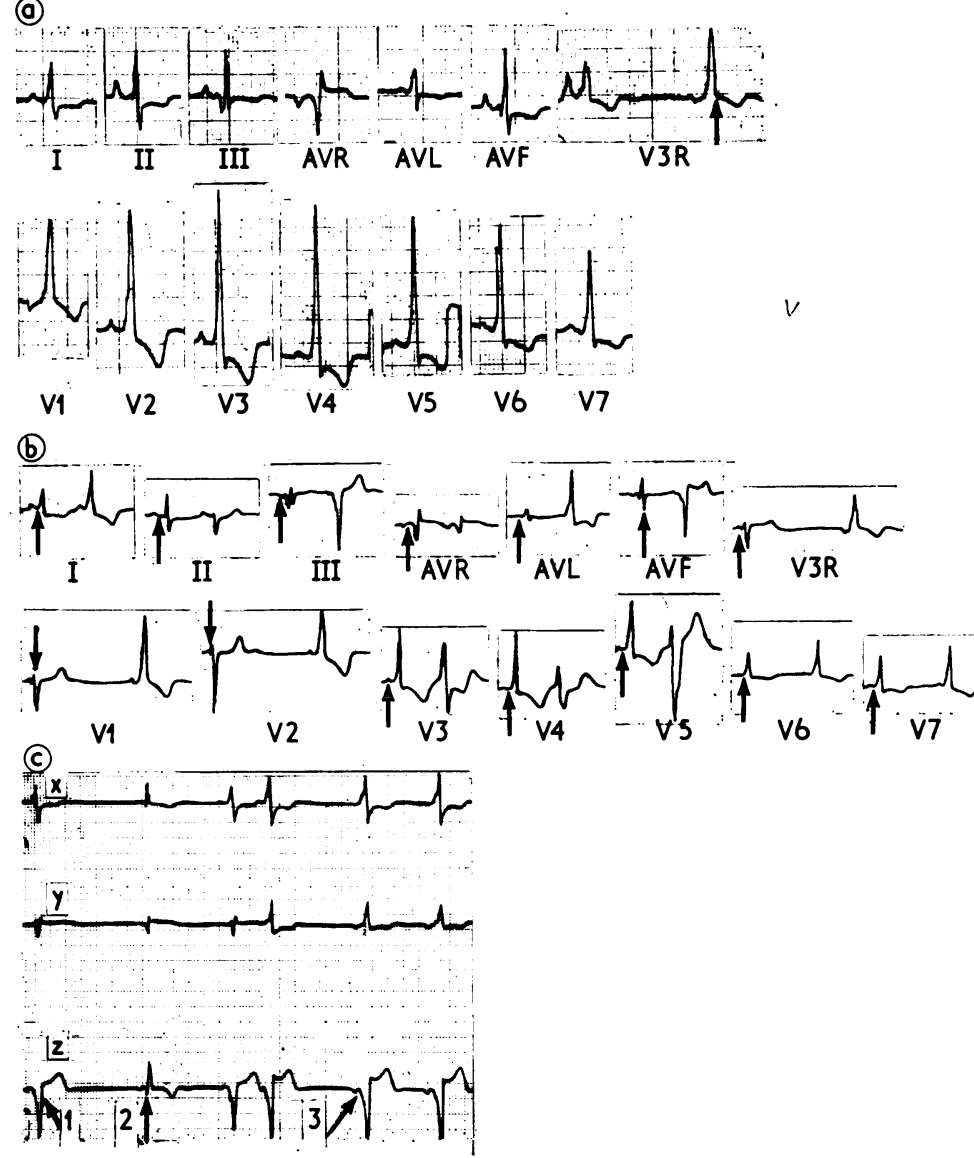

FIG. I Case I (a) Electrocardiogram shortly before death. Type A pattern of WPW syndrome. (b) Electrocardiogram of patient one year before being admitted to hospital. Type B pattern of WPW syndrome of the complexes, indicated by arrows. (c) Spatial $X, Y$, and $Z$ leads. Complex I: type A ?; complex 2: no $W P W$; complex 3: type $A+$ type $B$ ?

was Io $\mu \mathrm{m}$ in thickness. All the sections were stained alternately with haematoxylin and eosin, azan, silver protein according to Dankmeijer and Nauta (1939) and with resorcin-fuchsin-ironhaematoxylin-picric acid-thiazin red according to Hoefsmit (1967).

Results About I mm ventral to the dorsal interventricular sulcus were fibres, with features of conduction tissue as described and reviewed by Verduyn Lunel (1964), located subendocardially and connecting the right atrial with the right ventricular wall over a distance of $3 \mathrm{~mm}$ through holes in the annulus fibrosus (Fig. 2). Examining from here in a ventral direction no connexion was found over a distance of $2 \mathrm{~mm}$, and then myocardial fibres, together $7 \mathrm{~mm}$ in width, connected, 


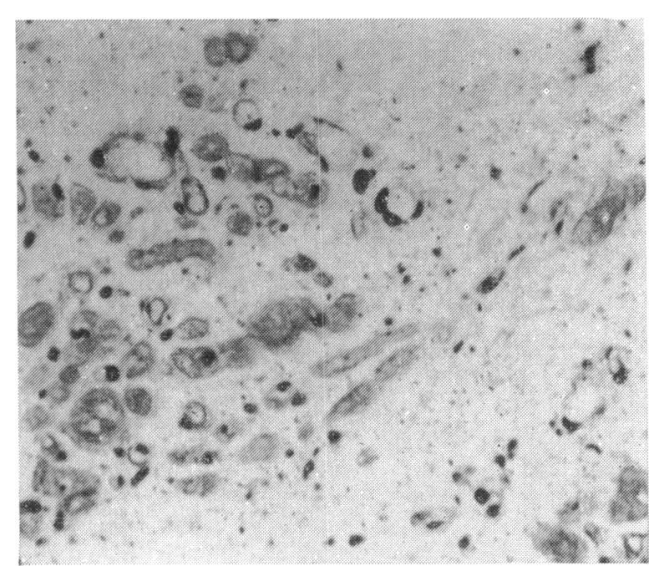

FIG. 2 Case 1. One of the connexions of conduction tissue between the lateral right parietal atrial and ventricular wall. (Silver protein. $\times 60$.)

subendocardially, the right atrial with the right ventricular wall through holes in the annulus fibrosus at right angles to the coronary sulcus (Fig. 3).

Between the ventral aspect of the right atrial and right ventricular wall very small myocardial fibres, together with a breadth of $2 \mathrm{~mm}$, were observed subendocardially at right angles to the coronary sulcus through holes in the annulus fibrosus.

Histological examination of the right lateral junction of the left atrial and ventricular wall failed to reveal any accessory connexion.

At the dorsal junction of the interatrial and interventricular septum the annulus fibrosus was

\section{FIG. 3 Case I. Subendocardial myocardial fibres (arrows) between the lateral right parietal atrial and ventricular wall. (Azan. $\times 9$.}

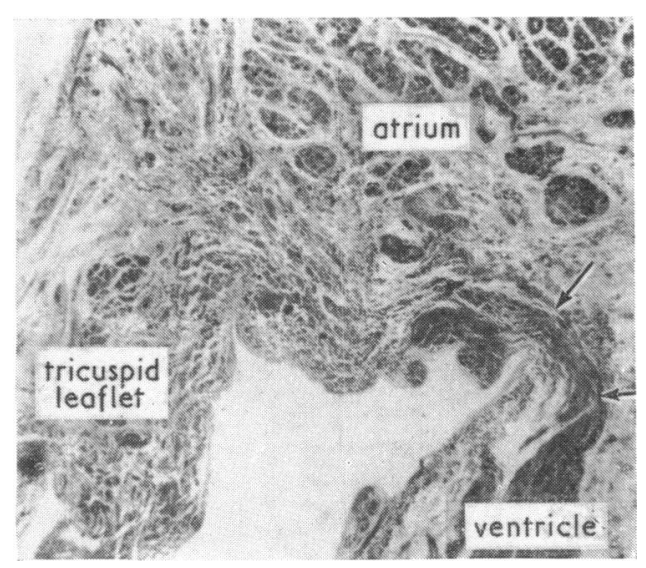

much more discontinuous than at its parietal part. Through many holes myocardial fibres connected the most dorsal part of the interatrial with that of the interventricular septum.

Reaching the His-Tawara bundle, large and abundant fibres of conduction tissue connected the AV node and the common bundle, respectively, with the basal rim of the interventricular septum through holes in the annulus fibrosus. The connecting nodal fibres were larger and more abundant than the bridges between the common bundle and the cephalic border of the interventricular septum (Fig. 4a, b, and c).

Case 2 A 17-year-old youth died suddenly at home. At the age of 13 years he was admitted to a hospital outside Leiden because of syncope in the break of a football match. In this condition, which continued for about one hour, no signs of epilepsy were noted. It was unknown whether the patient previously had attacks of tachycardia. The electrocardiogram showed type B of WPW syndrome (Fig. 5). A vectorcardiogram was not available. At necropsy (performed in the same hospital as the patient was admitted to at the age of 13 years) the results were briefly as follows.

Slight hypoplasia of both adrenal glands; hyperaemia of all organs; macroscopically, the heart did not show any abnormalities; the heart weight was $330 \mathrm{~g}$. The heart specimen was placed at the author's disposal for a histological examination.

Histological examination The following tissue blocks were taken from the heart specimen.

The right lateral junction of the right atrial and ventricular wall, with the dorsal interventricular sulcus and the adjacent lateral junction of the left atrial and ventricular wall. The junction of the left atrial and ventricular wall immediately dorsal to the tissue already mentioned. The dorsal junction of the interatrial and interventricular septum. Each of the tissue blocks was hardened and then embedded in paraffin. All the blocks were cut in serial sections at right angles to the coronary sulcus. The sections, each $10 \mu \mathrm{m}$ in thickness, were stained alternately with haematin-eosin, azan, and resorcin-fuchsin-iron haematoxylin-picric acidthiazin red according to Hoefsmit (1967).

Results About I mm ventral to the dorsal interventricular sulcus, myocardial fibres connected the right atrial with the right ventricular wall over a distance of $\mathrm{I} \mathrm{mm}$. These fibres were located subendocardially at right angles to the coronary sulcus through holes in the annulus fibrosus (Fig. 6a).

Between the left atrial and ventricular wall, immediately dorsal to the tissue block already mentioned, at the following three locations ordinary myocardial fibres were found subendocardially at right angles to the coronary sulcus through holes in the annulus fibrosus: (a) $2.0 \mathrm{~cm}$ dorsal to the dorsal interventricular sulcus, $0.8 \mathrm{~mm}$ in width; (b) $2.3 \mathrm{~cm}$ dorsal to the mentioned sulcus, more than $\mathrm{I} \mathrm{mm}$ in width; (c) at $2.8 \mathrm{~cm}$ dorsal to 
(a)

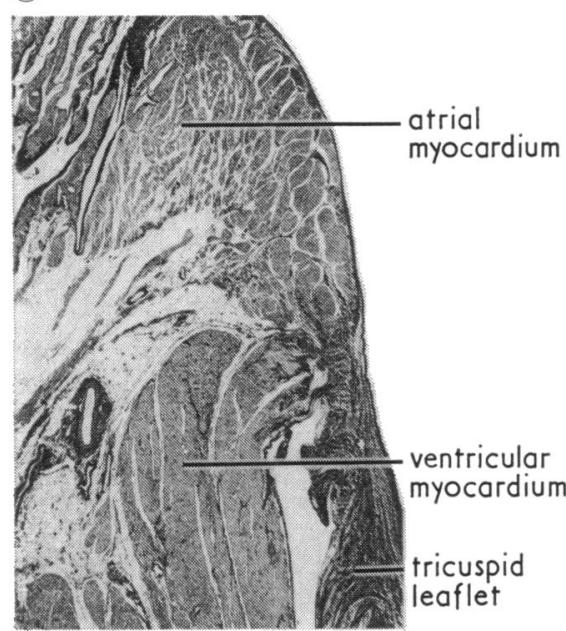

(b)

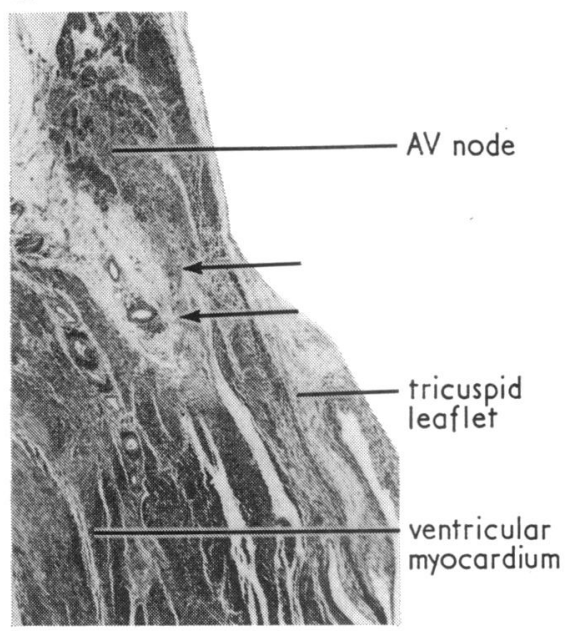

(c)

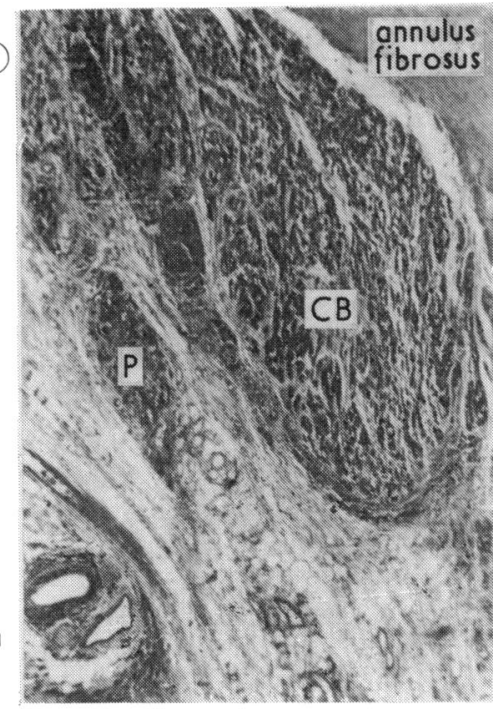

FIG. 4 Case I. (a) The most dorsal aspect of the junction of the interatrial and interventricular septum. Absence of the annulus fibrosus at this location. (Hoefsmit's stain. $\times 3).(b)$ One of the bridges of conduction tissue between the $A V$ node and the basal rim of the interventricular septum (arrows). No annulus fibrosus. (Azan. $\times 3.5$.) (c) A bridge of conduction tissue (P) between the common bundle $(C B)$ and the basal rim of the interventricular septum.

(Azan. × 13.)

the dorsal interventricular sulcus, more than 2 $\mathrm{mm}$ in width (Fig. 6b).

At the dorsal junction of the interatrial and the interventricular septum the following striking features were observed. (a) More than $3 \mathrm{~mm}$ ventral to the dorsal edge of the septum a $7 \mathrm{~mm}$ broad AV myocardial connexion was found through a big hole in the annulus fibrosus (Fig. 6c). (b) In this part of the septal AV junction, the AV node was connected with the underlying myocardium by offshoots of conduction tissue through holes in a discontinuous portion of the septal annulus fibrosus over a distance of more than I mm (Fig. 6d). (c) Between the penetrating portion of the common bundle and the cephalic rim of the ventricular septum, offshoots of conduction tissue were found over a distance of more than I $\mathrm{mm}$ through holes in the annulus fibrosus (Fig. $6 e)$. In addition the initial part of the left bundlebranch was connected with the basal rim of the ventricular septum by bridges of conduction tissue from the branch through holes in the annulus fibrosus.

\section{Discussion}

The results of the histological examinations with regard to ordinary myocardial accessory communications agree with those described by Kent (1893), Wood et al. (1943), Öhnell

FIG. 5 Case 2. Electrocardiogram, showing type $B W P W$ syndrome.

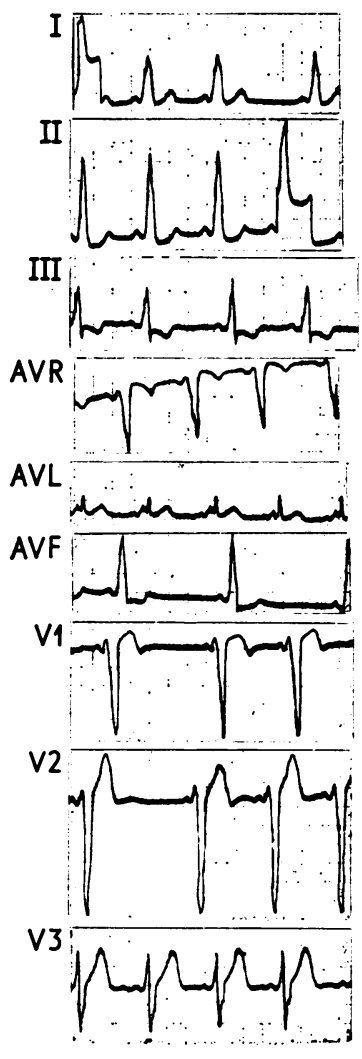

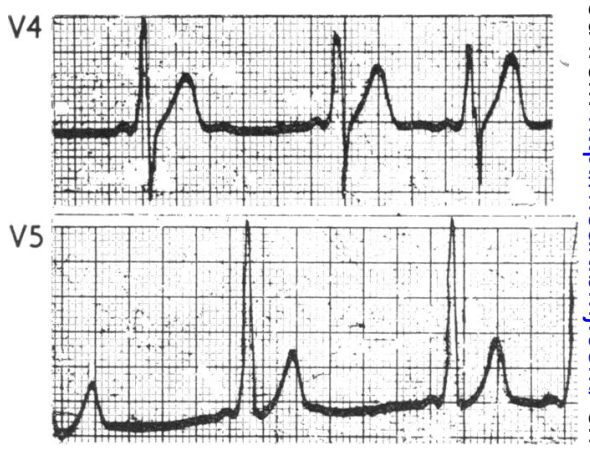

응 
(a)

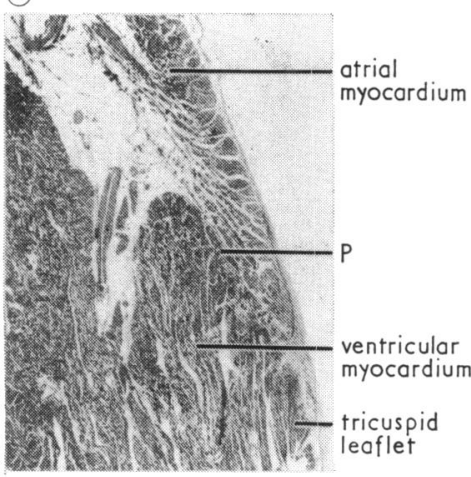

(b)

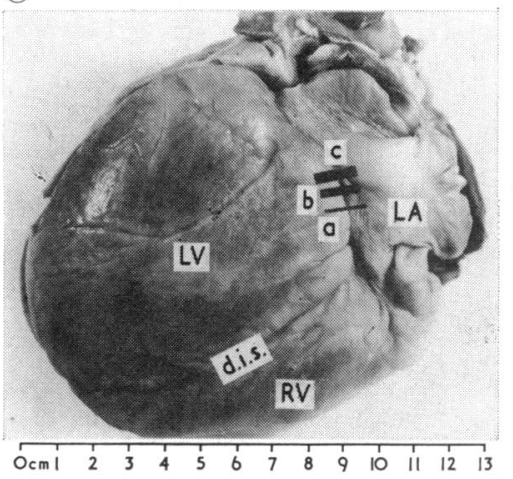

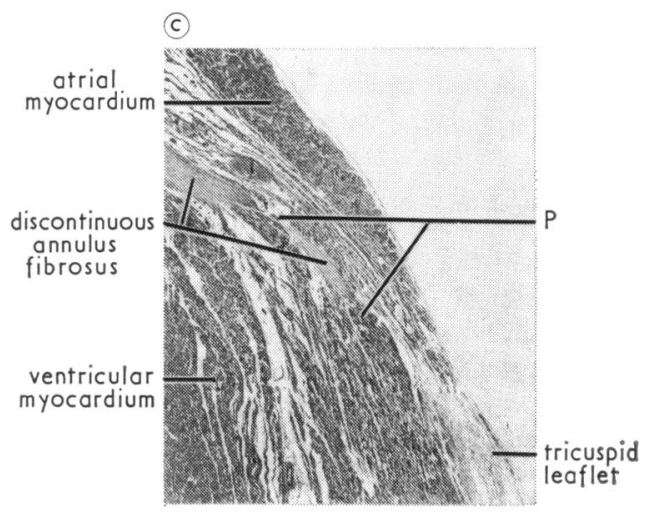

(d)

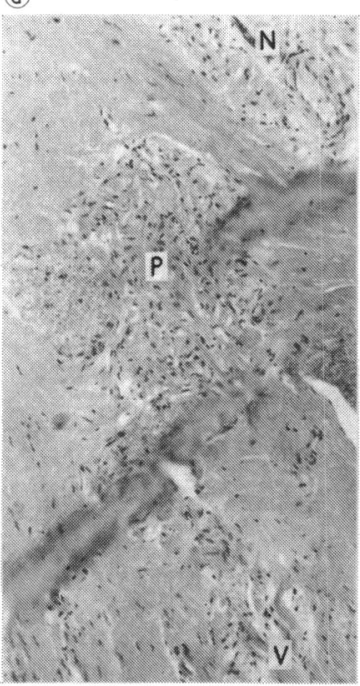

(e)

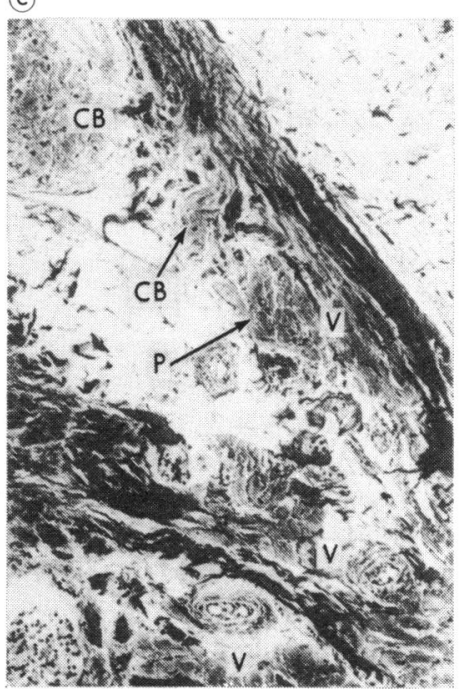

FIG. 6 Case 2. (a) Lateral junction of the right parietal atrial and ventricular wall. Continuity atrial and ventricular myocardium at $P$. No annulus fibrosus at this location. $($ Azan. $\times 2$.) (b) Areas $a, b$, and $c$, respectively, indicate subendocardial myocardial bridges between the left parietal atrial and ventricular wall. LA: left atrium; LV: left ventricle; d.i.s.: dorsal interventricular sulcus; $R V$ : right ventricle. (c) The most dorsal aspect of the septal junction of the atrium and ventricle. Continuity of atrial and ventricular myocardium through holes in the annulus fibrosus. (Azan. $\times 2$.) $(d)$ One of the bridges of conduction tissue $(P)$ between the AV node $(N)$ and the interventricular septum $(V)$. (Haematin-eosin. $\times 20$.) $(e)$ Continuity of the penetrating portion of the common bundle $(C B)$ and the basal rim of the interventricular septum $(V)$ at $P$. (Silver protein. $\times 20$.)

(1944), Lev et al. (1955, 1961, 1963), de Villeneuve and Schornagel (1958), and Truex et al. (1960). As far as the occurrence of modified accessory muscle bundles are concerned, the present findings were similar to those of Kent (I9I4 a, b, c) and Lev et al. (1966). Kent was the first author who drew attention toa discontinuous annulus fibrosus through which modified fibres connected the right ventricle with the right atrium (Fig. 7). ${ }^{1}$

1 Reproduced by permission of the Editorial Board of the fournal of Physiology.
Truex et al. (1958) stated that the development of the annulus fibrosus provided useful information concerning the origin of $\mathrm{AV}$ accessory muscle bundles and the mode of attachment of the atrial and ventricular muscle fibres in the adult heart. In I I of I 5 foetal and newborn human heart specimens under the age of 6 months, accessory connexions were observed, the majority of which connected a residual common bundle tissue mass with the basal rim of the ventricular septum through holes in the annulus fibrosus. In very early 
human embryos the musculature of the atrium was continuous with that of the ventricle. In $10 \mathrm{~mm}$ and $15 \mathrm{~mm}$ embryos a thin fenestrated layer with few connective tissues arose between atrium and ventricle; these compartments were connected with each other by large fascicles of cardiac muscle tissue through the holes. In advanced stages of gestation the connective tissue layer became a continuous, thick, and fibrous structure separating the atrial from the ventricular myocardium, while in most instances the muscular fascicles within the limits of the annulus fibrosus became interrupted. The atrial and ventricular ends of the interrupted fascicles behaved as insertions or cord-like attachments for the muscle bundles of the atrium and the ventricle. Truex $e t$ al. pointed out that in rare instances a large fascicle being composed of either conduction or ordinary myocardial tissue might persist in older embryos and during life as an accessory $\mathrm{AV}$ pathway.

In both heart specimens described in the present paper many holes were observed at different locations of the annulus fibrosus, in the parietal as well as in the septal part; the latter was found to be more discontinuous than the former. Through one hole at least one AV muscular connexion was noted; more ordinary myocardial or modified accessory fibres passed through one big gap. It was found that the quantity of these communications being potentially pathways of $\mathrm{AV}$ conduction was determined by the degree of discontinuity of the annulus fibrosus, which appeared to be the most important component of the histological substrate.

The offshoots of conduction tissue between the AV node and the common bundle, respectively, and the basal rim of the ventricular septum through holes in a discontinuous annulus fibrosus, found in both patients, would be important to ventricular activation disorders. The first patient suffered from repeated ventricular fibrillation shortly before death. It was not known whether the second patient had had previous attacks of tachycardia. However, in view of the sudden death it would be possible.

A previous example of a case in which only septal accessory AV connexions occurred was encountered by Lev et al. (1966) in a man of 34 years with Ebstein's anomaly combined with type B WPW syndrome. Many copious and abundant offshoots of parts of the HT bundle were found through holes in the annulus fibrosus to the basal rim of the ventricular septum. There were no muscular parietal ac-

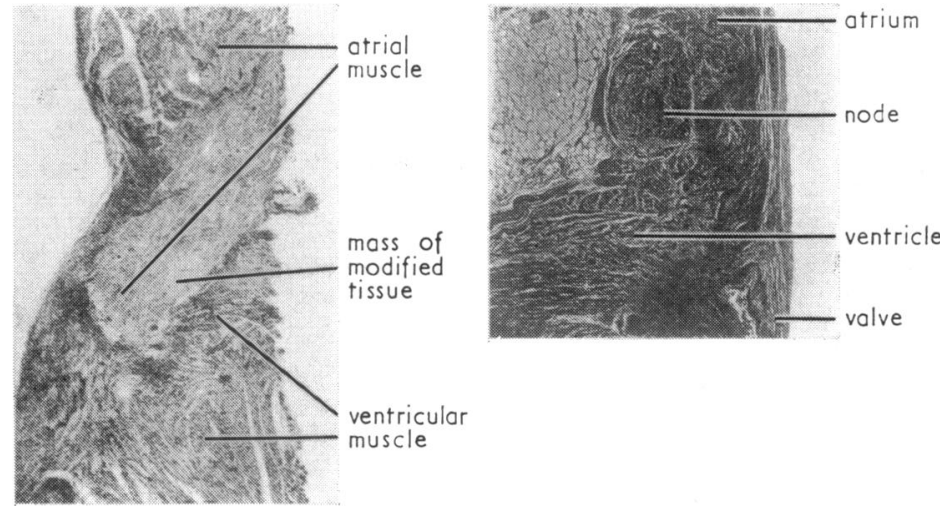

FIG. 7 Illustrations from Kent (Journal of Physiology, I9I 4a, c). On the left, atrial and ventricular myocardium were connected by modified tissue. On the right, the $A V$ node was continuous with the ventricular myocardium. In both sections from the right lateral $A V$ junction the connecting fibres passed through holes in the annulus fibrosus.

cessory fibres between atrium and ventricle, neither right- nor left-sided.

The classification of WPW complexes as type A or type B was introduced by Roserbaum et al. (1945) on the morphological basis of the praecordial and oesophageal electrocardiographic leads. The initial delta wave and the remainder of the QRS complex were stated to be primarily positive in both the right and left praecordial leads in type A where pre-excitation was assumed to occur in the left ventricle. The QRS complex with the initial delta wave was found to be negative in the right and positive in the left praecordial leads in cases of type B where pre-excitation was assumed to occur in the right ventricle.

The following accessory muscular AV connexions which have been described may illustrate the importance of the state of the annulus fibrosus in cases of WPW syndrome:

I) Parietal subendocardial accessory fibres, either right- or left-sided or at both sides (Wood et al., 1943; Öhnell, 1944; Levine and Burge, 1948; Lev et al., 1955, 196I, 1963; de Villeneuve and Schornagel, 1958).

2) Septal accessory fibres (Truex et al., 1960; Lev et al., 1966).

3) Parietal subendocardial and septal accessory fibres (Lev et al., 1955, 1963; this study). Any of the accessory muscular connexions between atrium and ventricle which were found through one gap or more holes in a 
more or less discontinuous annulus fibrosus may be related to WPW syndrome.

In normal hearts a few thin conduction fibres could connect parts of the His-Tawara bundle with the basal rim of the ventricular septum while the annulus fibrosus was well developed (Mahaim and Winston, I94I; Mahaim, 1947).

Other factors may be important to the genesis of WPW syndrome; the following data have been previously reported:

a) Inflammatory processes (Mahaim and Bogdanovic, 1948; Lev et al., 1963).

b) Coexistence with various forms of heart disease:-(i) in infants and children, WPW syndrome was found to be associated with coarctation of the aorta (Bodlander, 1946; Swiderski, Lees, and Nadas, I962), corrected transposition, primary myocardial disease (Swiderski et al., 1962), and Ebstein's anomaly, Swiderski et al., 1962; Lev et al., 1955, 1966); (ii) Braunwald (1964) described a classical WPW pattern of the electrocardiogram in 2 patients with hypertrophic subaortic stenosis; (iii) a WPW syndrome of type $B$ in a 21 year-old-woman with a large dorsal atrial septal defect (secundum type) was reported by Durrer and Roos (1967); and (iv) the first patient described in the present study showed coexistence with mitral stenosis.

c) Heredity factors: isolated familial preexcitation was described by Ohnell (1940), Doumer and Dumez (195I), Willis and Shepard (1953), McIntire and Freed (1955), Averill (1956), Harnischfeger (1959), and Schneider (1969).

It is necessary to examine carefully the parietal and septal junction of the atrial and ventricular wall in each heart specimen with WPW syndrome in order to ascertain whether the state of the annulus fibrosus may be responsible for the occurrence of accessory muscular AV connexions which could be potentially pathways of conduction.

Clinically Lamb (1959) demonstrated in a 4I-year-old man with WPW syndrome a number of phenomena: multiple variations in ventricular activation, intermittent normal conduction, variations in the PR interval with durations of $0.14 \mathrm{sec}$ in the presence of preexcitation and conversion to normal conduction. Matter and Hayes (1964) reported both type $A$ and type $B$ pre-excitation in another man of 4I years with paroxysmal tachycardia who also showed normal electrocardiograms at other times; this case seemed to be identical with the first patient described.

The variations in ventricular activation may be explained by a discontinuous annulus fibrosus which apparently showed a certain quantity of holes at different locations, creating pathways for accessory muscular AV connexions. Probably some of these fibres were conducting impulses at times while others did not, and conversely. At other periods none of the accessory fibres behaved as pathways of $\mathrm{AV}$ conduction.

A severely discontinuous annulus fibrosus, either at its parietal or at its septal part or at both portions, especially if many big accessory connexions between atrium and ventricle occurred, could provoke intraventricular conduction disturbances as in the first patient described and in the man reported by Lev et al. (1966). The clinical observations mentioned above are rare. On the other hand, one wonders whether those variations would be found more often if patients with WPW syndrome were observed continuously, especially by means of radiotelemetry. Then it would be possible to decide from moment to moment whether variations occur in WPW conduction.

\section{Conclusion}

Results of histological examinations of two heart specimens with WPW syndrome and of those already published, suggest that a discontinuous annulus fibrosus is an important component of the morphological substrate, which is related to the existence and progression of atrioventricular and intraventricular conduction anomalies.

The writer wishes to acknowledge with gratitude his indebtedness to Dr. G. Blomhert, Dr. F. Kalsbeek, and Dr. P. M. Bakker for their pathoclinical information concerning Case 2 where the heart specimen was placed at the author's disposal for a histological examination and to The fournal of Physiology, for their permission to reproduce two illustrations by Kent (r9r4).

\section{References}

Averill, J. H. (1956). Wolff-Parkinson-White syndrome occurring in brothers. American Heart fournal, 51, 943.

Bodlander, J. W. (I946). The Wolff-Parkinson-White syndrome in association with congenital heart disease: coarctation of the aorta. American Heart Fournal, 31, 785 .

Braunwald, E. (I964). Discussion following E. D. Wigle on Muscular subaortic stenosis: the clinical syndrome with additional evidence of ventricular septal hypertrophy. In CIBA Foundation Symposium, Cardiomyopathies, pp. II, and 71. Ed. by G. E. W. Wolstenholme and M. O'Connor. Churchill, London. 
Burchell, H. B., Frye, R. L., Anderson, M. W., and McGoon, D. C. (1967). Atrioventricular and ventriculoatrial excitation in Wolff-Parkinson-White syndrome (type B). Temporary ablation at surgery. Circulation, 36, 663 .

Cobb, F. R., Blumenschein, S. D., Sealy, W. C., Boineau, J. P., Wagner, G. S., and Wallace, A. G. (1968). Successful surgical interruption of the bundle of Kent in a patient with Wolff-ParkinsonWhite syndrome. Circulation, 38, ror8.

Dankmeijer, J., and Nauta, W. J. H. (1939). Eenige ervaringen met de protargolkleuring van zenuwvezels volgens Bodian. Nederlandsch Tijdschrift voor Geneeskunde, 83, 3846.

Doumer, E., and Dumez, L. (1951). Syndrome de Wolff-Parkinson-White familial. Syndrome de WPW avec PR apparemment normal sur certaines dérivations. Archives des Maladies du Coeur et des Vaisseaux, 44, II 34.

Durrer, D., and Roos, J. P. (1967). Epicardial excitation of the ventricles in a patient with WolffParkinson-White syndrome (type B). Circulation, $35,15$.

Durrer, D., Schoo, L., Schuilenburg, R. M., and Wellens, H. J. J. (1967). The role of premature beats in the initiation and termination of supraventricular tachycardia in the Wolff-ParkinsonWhite syndrome. Circulation, 36, 644.

Harnischfeger, W. W. (1959). Hereditary occurrence of the pre-excitation (Wolff-Parkinson-White) syndrome with re-entry mechanism and concealed conduction. Circulation, 19, 28.

Hoefsmit, E. Chr. M. (1967). Het sluitingsproces van de ductus arteriosus bij de rat. Een micro-anatomisch onderzoek met gestandaardiseerde kleurmethoden. (Thesis, Leiden.) Drukkerij Albani, The Hague. (Summary in English).

Kent, A. F. S. (1893). Researches on the structure and function of the mammalian heart. Fournal of Physiology, 14, 233.

Kent, A. F. S. (I9I4a). The right lateral auriculoventricular junction of the heart (abstract). fournal of Physiology, 48, 22.

Kent, A. F. S. (1914b). A conducting path between the right auricle and the external wall of the right ventricle in the heart of the mammal (abstract). Fournal of Physiology, 48, 57.

Kent, A. F. S. (I9I4C). Illustrations of the right lateral auriculoventricular junction in the heart (abstract). Fournal of Physiology, 48, 63.

Lamb, L. E. (1959). Multiple variations of WPW conduction in one subject. Intermittent normal conduction and a false positive exercise tolerance test. American fournal of Cardiology, 4, 346.

Lev, M., Gibson, S., and Miller, R. A. (1955). Ebstein's disease with Wolff-Parkinson-White syndrome. Report of a case with a histopathologic study of possible conduction pathways. American Heart fournal, 49, 724.

Lev, M., Kennamer, R., Prinzmetal, M., and De Mesquita, Q. H. (I96I). A histopathologic study of the atrioventricular communications in two hearts with the Wolff-Parkinson-White syndrome. Circulation, 24, 4I.

Lev, M., Leffler, W. B., Langendorf, R., and Pick, A. (I966). Anatomic findings in a case of ventricular pre-excitation (WPW) terminating in complete atrioventricular block. Circulation, 34, 718.

Lev, M., and Lerner, R. (1955). The theory of Kent. A histologic study of the normal atrioventricular communications of the human heart. Circulation, 12, 176.

.ev, M., Sodi-Pallares, D., and Friedland, C. (1963). A histopathologic study of the atrioventricular communications in a case of WPW with incomplete left bundle branch block. American Heart fournal, 66, 399.

Levine, H. D., and Burge, J. C. (1948). Septal infarction with complete heart block and intermittent anomalous atrioventricular excitation (Wolff-Parkinson-White syndrome). Histologic demonstration of a right lateral bundle. American Heart fournal, 36, 43 I.

McIntire, M. S., and Freed, A. E. (1955). WolffParkinson-White syndrome. Report of a case in a mother and infant. American fournal of Diseases of Children, 89, 743 .

Mahaim, I. (1947). Kent's fibres and the atrioventricular paraspecific conduction through the upper connections of the bundle of His-Tawara. American Heart fournal, 33, 65I.

Mahaim, I., and Bogdanovic, P. (1948). Un cas mortel de syndrome de Wolff-Parkinson-White. Lésions inflammatoires chroniques du faisceau de HisTawara. Acta Medica Iugoslavica, 2, 137.

Mahaim, I., and Winston, M. (194I). Recherches d'anatomie comparée et de pathologie expérimentale sur les connections hautes du faisceau de HisTawara. Cardiologia, 5, 189.

Matter, B., and Hayes, W. L. (1964). Wolff-ParkinsonWhite syndrome. Report of a case with both type A and type B pre-excitation. American fournal of Cardiology, 13, 284.

Öhnell, R. F. (1940). Post mortem examination and clinical report of a case of the short P-R interval and wide QRS wave syndrome (Wolff-ParkinsonWhite). Cardiologia, 4, 249.

Öhnell, R. F. (1944). Pre-excitation. A cardiac abnormality. Acta Medica Scandinavica, 117, Suppl. 152.

Orinius, E. (1967). Pre-excitation. Studies on criteria, prognosis and heredity. Acta Medica Scandinavica, 181, Suppl. 465, I.

Roelandt, J., and Van der Hauwaert, L. (1968). Atrial reciprocal rhythm and reciprocating tachycardia in Wolff-Parkinson-White syndrome. Circulation, 38, 64.

Rosenbaum, F. F., Hecht, H. H., Wilson, F. N., and Johnston, F. D. (1945). The potential variations of the thorax and the esophagus in anomalous atrioventricular excitation (Wolff-Parkinson-White syndrome). American Heart fournal, 29, $28 \mathrm{I}$.

Schneider, R. G. (1969). Familial occurrence of WolffParkinson-White syndrome. American Heart fournal, 78, 34 .

Swiderski, J., Lees, M. H., and Nadas, A. S. (1962). The Wolff-Parkinson-White syndrome in infancy and childhood. British Heart fournal, 24, 561.

Tawara, S. (1906). Das Reizleitungssystem des Säugetierherzens. Eine anatomischhistologische Studie über das Atrioventrikularbündel und die Pur-kinjeschen Fäden. Gustav Fischer, Jena.

Truex, R. C., Bishof, J. K., and Downing, D. F. (1960). Accessory atrioventricular muscle bundles. II. Cardiac conduction system in a human specimen with Wolff-Parkinson-White syndrome. Anatomical Record, 137, 417.

Truex, R. C., Bishof, J. K., and Hoffman, E. L. (1958). Accessory atrioventricular bundles of the developing human heart. Anatomical Record, 131, 45.

Verduyn Lunel, A. A. (1964). De localisatie van het atrioventriculaire geleidingssysteem bij normale harten en aangeboren openingen in het septum cordis. (Thesis, Leiden.) Drukkerij Albani, The Hague. (Summary in English.)

de Villeneuve, V. H., and Schornagel, H. E. (1958). Voorkomen van een accessoire atrioventriculaire spierbundel bij een zuigeling met paroxysmale tachycardie en het Wolff-Parkinson-White syndroom. Maandschrift voor Kindergeneeskunde, 26, 23. 
Willis, W. H., and Shepard, C. C. (1953). The familial incidence of certain unusual diseases. Northern New York Medical fournal, 10, 19.

Wolff, L., Parkinson, J., and White, P. D. (1930). Bundle-branch block with a short P-R interval in healthy young people prone to paroxysmal tachycardia. American Heart fournal, 5, 685.

Wood, F. C., Wolferth, C. C., and Geckeler, G. D.
(1943). Histologic demonstration of accessory muscular connections between auricle and ventricle in a case of short P-R interval and prolonged QRS complex. American Heart fournal, 25, 454.

Requests for reprints to Dr. Antoine A. Verduyn Lunel, Department of Cardiology, Academic Hospital, Leiden, The Netherlands. 